\title{
Faktor-Faktor Penentu Pengambilan Keputusan dalam Upaya Meningkatkan Penjualan Usaha Roti Bunda di Keputih Surabaya
}

\author{
NOVI RISTIYASARI HIDAYATI
}

noviristiya@gmail.com

\author{
Mahasiswa Fakultas Ekonomi dan Bisnis Universitas Narotama
}

\begin{abstract}
ABSTRAK
Tujuan dari studi ini adalah untuk mengetahui faktor-faktor penentu pengambilan keputusan dan mengetahui proses dan cara meningkatkan penjualan. Penelitian ini merupakan penelitian deskriptif dan bersifat kualitatif. Penelitian ini hanya menggunakan narasumber sebagai informasi utama yang dibutuhkan. Pengambilan keputusan yang efektif dapat berpengaruh terhadap peningkatan hasil penjualan.
\end{abstract}

Kata Kunci; Pengambilan Keputusan, Penelitian deskriptif, peningkatan penjualan

\section{PENDAHULUAN}

\subsection{Latar Belakang}

Dunia bisnis sedang berkembang pesat akhir-akhir ini. Para pelaku usaha dipaksa untuk berhadapan dengan persaingan yang begitu ketat. Perencanaan yang benar dan pengambilan keputusan yang sesuai berpengaruh terhadap kelangsungan usaha tersebut.

Salah satu bisnis yang sedang berkembang saat ini adalah bisnis kuliner/makanan. Di pulau Jawa sendiri, khususnya di Jawa Timur, masyarakatnya banyak yang menggemari makanan manis, seperti kue basah/kue tradisional, jajanan kering baik itu roti, biskuit, dan lain sebagainya.

Para pelaku bisnis harus jeli melihat segmentasi pasar dan target yang ingin dicapai. Hal ini berguna agar para pelaku usaha tersebut mendapatakan hasil keuntungan seefektif mungkin dengan pengeluaran biaya yang tepat guna, mengingat saat ini biaya produksi maupun nonproduksi cukup mahal di pasaran akibat adanya inflasi gejolak ekonomi yang tidak pasti dan lesunya pertumbuhan ekonomi global.

Selain berhubungan dengan masalah pembiayaan salah satu faktor yang cukup berpengaruh adalah pengambilan keputusan dalam menentukan produk yang akan dijual agar sesuai dengan perencanaan yang telah dibuat. Untuk itulah makalah ini kami susun sebagai salah satu contoh penelitian mengenai salah satu contoh pengambilan keputusan usaha, khususnya bidang kue/roti.

\subsection{Rumusan Masalah}

1. Apasaja faktor-faktor penentu dalam pengambilan keputusan di Toko Roti Bunda?

2. Bagaimana faktor-faktor tersebut mempengaruhi peningkatan penjualan di Toko Roti Bunda?

1.3 Tujuan

1. Mengetahui faktor-faktor penentu dalam pengambilan keputusan di Toko Roti Bunda.

2. Mengetahui faktor-faktor tersebut mempengaruhi peningkatan penjualan di Toko Roti Bunda. 


\section{TINJAUAN PUSTAKA}

Dalam kehidupan sehari-hari kita selalu dihadapkan dengan istilah organisasi. Organisasi bisnis biasanya bertujuan untuk mencari keuntungan finansial, organisasi kemasyarakatan biasanya bertujuan untuk tujuan kemasyarakatan, organisasi politik biasanya untuk tujuan kekuasaan dan organisasi keagamaan biasanya untuk tujuan misi atau dakwah. Tujuan tersebut menurut AsakuWalisongo (2013) dicerminkan oleh sasaran yang harus dilakukan baik dalam jangka pendek, maupun jangka panjang. Implementasinya setiap organisasi merumuskan visi, misi, serta tujuan baik jangka pendek, menengah maupun jangka panjang.

Setiap organisasi tentu memiliki pemimpin dan kepemimpinan. Biasanya pemimpin memiliki pengaruh lebih besar dalam upaya pencapaian tujuan organisasi, oleh karena pemimpin sering diistilahkan dengan orang yang mempengaruhi bawahan untuk mencapai tujuan yang diharapakan. Pendapat itu sejalan dengan yang disampaikan oleh Husaini Usman (2013:312), kepemimpinan ialah ilmu dan seni mempengaruhi, orang atau kelompok untuk bertindak seperti yang diharapkan untuk mencapai tujuan secara efektif dan efisien. Jadi jelas bahwa pemimpin memiliki pengaruh besar terhadap sukses tidaknya sebuah oraganisasi.

Salah satu fungsi yang harus dilakukan pemimpin dalam upaya pencapaian tujuan adalah bagaimana pemimpin itu bisa mengambil keputusan dengan efektif. Dalam realita pengambilan keputusan bukanlah hal yang sedernana, sebab setiap pengambilan keputusan biasanya mengandung dua konsekuensi sekaligus baik konsekuensi positif maupun konsekuensi negatif. Namun demikian seorang pemimpin harus berani mengambil keputusan dari beberapa pilihan yang dihadapai.

Seorang pemimpin diharapkan mengikuti pendapat Terry dalam Marzuki (2015: 2), bahwa dalam mengambil keputusan hendaklah memilih yang terbaik dari berbagai altenatif yang tersedia. Salah satu tugas terpenting seorang pemimpin adalah untuk menentukan yang terbaik bagi organisasi dan para anggotanya. Namun dalam mengambil keputusan, terkadang pemimpin pun menghadapi dilema dan seolah berada di persimpangan jalan.

Kecepatan dan ketepatan seorang pemimpin dalam mengambil keputusan lazimnya menjadi tolak ukur kompetensi dan kredibilitas yang dimilikinya. Jika pemimpin lamban dan ragu-ragu dalam bertindak, anak buah akan melihat bahwa pemimpin tersebut adalah pemimpin yang tidak berani mengambil resiko. Terbiasa cepat dalam pengambilan keputusan memang bukan pekerjaan mudah, butuh rasio yang jernih dan intuisi yang tajam agar bisa menghasilkan keputusan yang tepat. Menarik untuk dikaji bagaimana seorang pemimpin bisa mengambil keputusan dengan baik, dalam pengertian efektif, efisien, meminimalkan resiko, serta bermanfaat bagi kemajuan organisasi dalam rangka pencapaian tujuan yang diharapkan.

\section{Pengertian Pengambilan Keputusan}

Drommond (1985) berpendapat bahwa pengambilan keputusan merupakan usaha penciptaan kejadian-kejadian dan pembentukan masa depan (peristiwa-peristiwa pada saat pemilihan dan sesudahnya). Pendapat ini menegaskan bahwa pengambilan keputusan merupakan proses pada saat sejumlah langkah yang harus dilakukan dengan pengevaluasian alternatif untuk membuat putusan dari semua alternatif yang ada (Syaruddin:48). 
dari beberapa definisi dijelaskan di atas, maka disimpulkan bahwa pengambilan keputusan adalah proses pemecahan masalah dengan menentukan pilihan dari beberapa alternatif untuk menetapkan suatu tindakan yang ingin dilakukan dalam mencapai tujuan yang diinginkan.

\section{Pengambilan keputusan dengan kreatif dan inovatif.}

Pengambilan keputusan dengan tidak kreatif mempunyai kecenderungan untuk membuat keputusan secara emosional. Dengan menggunakan kreativitasnya, pengambilan keputusan dapat menemukan alternatif-alternatif untuk memecahkan masalah, kemudian memilih salah satu alternatif yang bermanfaat bagi pencapaian organisasi. Inovasi memungkinkan pengambilan keputusan melaksanakan keputusan dengan baik.

\section{Berdasarkan jenis problemnya dikelompokkan menjadi:}

Pengambilan keputusan terprogram, yaitu pembuatan keputusan dapat dilakukan dengan menggunakan standar prosedur operasi rutin. Cirinya adalah:

- Problemnya terstruktur, sederhana dan informasinya tersedia lengkap.

- Problem dan proses pembuatan keputusannya sudah berulang-ulang terjadi sehingga sudah dapat diperhitungkan dan mempunyai pengalaman menyelesaikannya.

- Pengambilan keputusan tidak terprogram ialah pengambilan keputusan yang problemnya unik, belum pernah terjadi. Informasi mengenai problem belum tersedia atau sedikit, peraturan, kebijakan, prosedur operasi standar untuk membuat keputusan yang belum ada. (Wirawan, 2014:556).

- Pengaruh Pengambilan Keputusan yang Efektif bagi Kemajuan Organisasi

Sebagai mana yang telah dipaparkan oleh Usman, Husaini (2013: 312), bahwa kemajuan suatu organisasi dipengaruhi oleh cara pemimpin dalam mengambil keputusan. Telah dilakukan beberapa penelitian yang searah dengan pendapat Usman (2013) tersebut. Juliyanti, Mohammad Isa Irawan, dan Imam Mukhlash (2011) melakukan penelitian tentang Pemilihan guru Berprestasi menggunakan metode AHP-TOPSIS. Penelitian tersebut menghasilkan temuan yaitu adanya suatu sistem pengambilan keputusan dapat membantu proses pemilihan berdasarkan kriteria-kriteria yang ditentukan sehingga bisa dilakukan proses perhitungan yang lebih efektif dan efesien.

Roopa Singh dan Imran A. Khan dari Shri JJT University India (2012) dalam studinya yang berjudul "An Approach to Increase Customer Retention and Loyalty in B2C World" mengemukakan bahwa aksi kecil perusahaan dengan sedikit kompromi pada keuntungan akan berubah menjadi loyalitas jangka panjang oleh pelanggan- "short term actions with bit compromise with the profit will turn into long term customer loyalty".Ada beberapa cara untuk menumbuhkan retensi pelanggan menurut penelitian tersebut, antara lain : (1) Memberikan Payback (semacam pembelian dengan metode cicilan berjangka yang mengedepankan keringanan pembayaran dan system investasi yang mudah, (2) Diskon berdasarkan waktu dan volume pembnelian, (3) Paket barang, (4) Membership / Program Keanggotaan, (5) Kebijakan pengembalian barang untuk loyal customer. Nur hayati (2011) dalam studinya yang berjudul Pengaruh Kepuasan Pelanggan, Kepercayaan Pelanggan terhadap Loyalitas pelanggan pengguna kartu seluler Indosat. Hasil penelitian menunjukkan bahwa model terbaik adalah Model Teoritis 2. Dalam pelanggan model 2 kepercayaan digambarkan sebagai yang ke mempengaruhi loyalitas pelanggan dibandingkan dengan Model Teoritis 1 dengan kepuasan pelanggan sebagai anteseden. Model menunjukkan hubungan yang signifikan kepercayaan dengan kepuasan dan kesetiaan pelanggan. Murali Chandrashekaran, Kristin Rotte, Stephen S. Tax, and Rajdeep Grewal (2007) Satisfaction Strength and Customer Loyalty. Dalam studinya menyatakan kepuasan pelangganmenjadi dua tingkat aspek-kepuasan dan kepuasan terkait tetapi independen kekuatan-dan kemudian memeriksa peran kekuatan kepuasan dalam 
terjemahan kepuasan dalam loyalitas. Dengan menggunakan data dari studi pelacakan kepuasan pelanggan yang sedang berlangsung yang dilakukan oleh organisasi layanan berbasis di AS yang besar, Studi 1 mengkaji peran kekuatan kepuasan dalam membentuk link kepuasanloyalitas dalam pengaturan bisnis-kebisnis. Penelitian 2, replikasi konseptual dalam konteks bisnis -ke-konsumen, meneliti hubungan hipotesis dalam situasi kegagalan layanan /pemulihan. Studi kuat menunjukkan bahwa kekuatan kepuasan memainkan peran sentral dalam terjemahan kepuasan menyatakan dalam loyalitas. Temuan utama adalah bahwa meskipun kepuasan diterjemahkan ke dalam loyalitas ketika kepuasan sangat diadakan (ketidakpastian yaitu, rendah), terjemahan secara signifikan menurunkan rata-rata sekitar 60\% ketika kepuasan yang sama lebih lemah diadakan (ketidakpastian yaitu, tinggi). Penelitian juga menunjukkan bahwa aspek hubungan sebelumnya (lamanya hubungan, volume bisnis, dan kemampuan menyukai dari pengalaman sebelumnya) mengakibatkan kerentanan lebih besar. Griffin (2002:5) berpendapat bahwa pelanggan yang loyal adalah pelanggan yang sangat puas dengan produk atau jasa tertentu sehingga mempunyai antusiasme untuk memper kenalkannya kepada siapapun yang dikenal. Sedangkan Menurut Kotler dan Keller (2009:139) loyalitas pelanggan merupakan komitmen pelanggan terhadap suatu merk dan pemasok, berdasarkan sikap yang positif dan tercermin dalam pembelian yang konsisten

\section{METODE PENELITIAN}

Dalam kaitan ini Arief Furchan (1999: 22) menerangkan sebagai berikut:

Metode kualitatif ialah "proses penelitian yang menghasilkan data deskriftif, ucapan atau tulisan atau perilaku yang dapat diamati dari orang-orang itu sendiri, menurut pendapat kami pendekatan ini langsung menunjukan setting dan individu-individu dalam setting itu secara keseluruhan. Subyek penyelidikan baik berupa organisasi atau individu tidak mempersempit menjadi variable yang terpisah atau menjadi hipotesa melainkan dipandang sebagai suatu keseluruhan. Dari pendapat diatas, dapat dikatakan bahwa pendekatan kualitatif berusaha mendapatkan data deskriptif, ucapan atau tulisan dan perilaku yang dapat diamati.

Dalam penelitian ini digunakan pendekatan kualitatif dengan alasan mengacu pada beberapa alasan sebagai mana yang dikemukakan oleh. Margono (2000: 37) antara lain:

1. Untuk menanggulangi banyaknya informasi yang hilang, seperti yang dialami oleh penelitian kualitatif sehingga intisari konsep yang ada pada data dapat diungkap.

2. Untuk menaggulangi kecenderungan menggali data empiris dengan tujuan membuktikan kebenaran hipotesis akibat dari adanya hipotesis yang disusun sebelumnya berdasarkan berfikir deduktif seperti dalam pemikiran kuantitatif.

3. Untuk menanggulangi kecenderungan pembatasan variable yang sebelumnya, seperti dalam penelitian kuantitatif padahal permasalahan dan variable dalam masalah social sangat kompleks.

4. Untuk menanggulangi adanya indeks-indeks kasar seperti dalam penelitian kuantitatif yang menggunakan pengukuran enumerasi (perhitungan) empiris, padahal inti sebenarnya berada pada konsep-konsep yang timbul dari data.

\section{Prosedur Pengumpulan Data}

Dalam penelitian kualitatif, peneliti sekaligus berfungsi sebagai instrument utama yang terjun kelapangan serta berusaha sendiri mengumpulkan data melalui wawancara dan interview. 
Metode Interview

Metode ini disebut juga dengan metode wawancara, yaitu suatu metode pengumpulan data yang dilakukan melalui Tanya jawab secara langsung dengan sumber data.

Sehungan dengan hal ini Margono (2003: 165) mengemukakan bahwa: "interview merupakan alat pengumpulan informasi dengan cara mengajukan pertanyaan secara lisan, untuk dijawab secara lisan juga, cirri utama dari interview adalah kontak langsung dengan tatap muka antara pencari informasi dengan sumber informasi”.

Analisis data penelitian kualitatif pada dasarnya sudah dilakukan sejak awal kegiatan penelitian sampai akhir penelitian. Dengan cara ini diharapkan terdapat konsistensi analisis data secara keseluruhan. Karena mengingat penelitian ini bersifat deskriptif, maka digunakan analisa data filosofis atau logika yaitu analis deduktif.

Metode deduktif adalah metode berpikir dengan mengambil kesimpulan dari data-data yang bersifat umum.

Dalam penelitian ini digunakan metode deduktif untuk menarik suatu kesimpulan terhadap halhal atau peristiwa-peristiwa dari data yang telah dikumpulkan melalui wawancara, yang bisa dikhususkan (ditarik kearah kesimpulan khusus), maka jelas metode induktif ini untuk menilai fakta-fakta empiris yang ditemukan lalu dicocokan dengan teori-teori yang ada.

\section{PEMBAHASAN}

Usaha kue menjadi trend di kalangan masyarakat, khusunya di Surabaya. Kue kini merupakan bagian penting dalam pemenuhan kebutuhan makanan. Hal ini dikarenakan tampilan, rasa dan porsi kue yang beragam, mulai dari kue basah/kue tradisional, kue kering, bakery maupun biscuit. Bahan dasar kue yang menggunakan tepung terigu/tepung beras yang banyak mengandung karbohidrat, cocok untuk dijadikan pengganti nasi bagi sebagian orang.

Usaha kue cukup menjanjikan profit yang besar. Usaha ini tidak hanya digeluti oleh UMKM (Usaha Mikro Kecil dan Menengah), namun juga perusahaan besar, seperti Sari Roti, Paroti, dan sebagainya. Hal ini tentunya menjadi ancaman bagi pelaku UMKM (Usaha Mikro Kecil dan Menengah) karena faktor sumber daya, keuangan, koneksi dan lainnya. Ancaman ini harus disiasati oleh pelaku UMKM supaya tetap survive menghadapi persaingan.

Diperlukan berbagai macam faktor agar pelaku UMKM (Usaha Mikro Kecil dan Menengah) khususnya dalam bidang kue $\&$ roti, untuk bertahan. Salah satu faktor yang penting adalah pengambilan keputusan dalam proses operasional usaha. Pengambilan keputusan ini berguna untuk meningkatkan penjualan. Sebagai contoh adalah usaha Roti Bunda di Keputih Surabaya.

Bunda Rina membuka usaha Roti Bunda pada tahun 2014. Berbekal khursus dalam acara PKK di Kelurahan Keputih beliau mencoba peruntungannya dalan usaha Roti. Awalnya Roti yang ia jual adalah jenis bakery. Dalam memproduksi kue beliau dibantu oleh 1 orang karyawan. Selain berjualan di toko setiap hari, toko roti ini juga menerima pesanan untuk acaraacara, misal pernikahan, pengajian, rapat, dll. Harga kue di toko ini cukup terjangkau, berkisar antara $\operatorname{Rp} 2.500,00$ sampai $\operatorname{Rp} 4.000,00$.

Suatu ketika, bunda Rina memperoleh pesanan yang cukuo banyak, beliau dan 1 orang karyawannya merasa kewalahan dalam memenuhi pesanan tersebut. Akhirnya bunda Rina meminta bantuan salah satu tetangganya yang kini resmi menjadi karyawannya juga. Karyawan baru tersebut rupanya pernah berjualan kue basah produksi sendiri. Hal ini dimanfaatkan oleh 
bunda Rina untuk memperluas usahanya. Dari yang semula hanya berjualan kue kering/ bakery, kini bertambah dengan varian kue basah. Setiap hari toko roti ini mampu memproduksi 250 kue kering/bakery dengan 5 varian dan 150 kue basah dengan 5 varian. Setelah mulai memperoduksi kue basah, bunda Rina melihat bahwa penjualan cenderung stagnan dan tidak ada perbedaan dengan sebelumnya.

Bunda Rina kemudian berpikir untuk menghilangkan varian kue basah. Namun sebelumnya bunda Rina mensurvei terlebih dahulu sebelum benar-benar menutup varian kue basah. Dari hasil survei membuktikan bahwa tidak semua kue basah tidak disenangi oleh masyarakat. Akhirnya diputuskan bahwa kue basah akan tetap dibuat dengan proporsi tertentu dan hanya produk tertentu saja.

Faktor-faktor yang menentukan keputusan dari bunda Rina adalah :

1. Harga

Faktor ini dikarenakan kondisi ekonomi masyarakat sekitar Keputih yang mayoritas mahasiswa dan keluarga kelas menengah.

2. Segmentasi

Segmentasi untuk masyarakat sekitar Keputih adalah mahasiswa dan keluarga kelas menengah.

3. Varian Kue Basah

Terdapat beberapa jenis kue basah yang sangat laris yaitu Resol, Lumpia dan Klepon. Namun ada juga kue basah yang tidak laku sama sekali yaitu Jemblem, Nagasari.

4. Permintaan

Dari beberapa varian kue basah, Risol dan Lumpia menjadi produk dengan predikat permintaan terbanyak.

Akhirnya dengan mengetahui ke empat faktor tersebut, penjualan kue basah kini di toko Roti Bunda produksinya dikurangi menyesuaikan dengan produk yang laris saja. Secara produksi memang terlihat ada penurunan, namun secara penjualan, penjualan tetap stabil karena tidak ada produk sisa di akhir hari (terjual habis).

\section{KESIMPULAN}

Dari berbagai uraian di atas maka dapat disimpulkan bahwa :

Pengambilan keputusan merupakan proses yang penting dalam keberlangsungan usaha khusunya UMKM (Usaha Mikro Kecil dan Menengah) yang memiliki sumber daya terbatas. Faktor-faktor yang menjadi penentu pengambilan keputusan untuk peningkatan penjualan meliputi Harga, Segmentasi, Varian, dan Permintaan.

Berdasarkan penelitian keempat faktor diatas mempengaruhi pengambilan keputusan UMKM untuk berproduksi demi memenuhi kepuasan pelanggan sekaligus mencapai keuntungan yang diharapkan/direncanakan. 


\section{DAFTAR PUSTAKA}

Alimudin, A. (2015). Strategi pengembangan minat wirausaha melalui proses pembelajaran. E-Jurnal Manajemen Kinerja, 1(1).

Alimudin, A., \& Yoga, H. (2015). STRATEGI MENINGKATKAN LOYALITAS PELANGGAN PADA USAHA KECIL PRODUK MAKANAN RINGAN DI SURABAYA. Sustainable Competitive Advantage (SCA), 5(1).

Anzizhan, Syafaruddin. Sistem pengambilan keputusan pendidikan. Ebook.

Anonim. 2013. Pengertian, Tujuan, dan Manfaat Organisasi (https://www.contohlengkap.com/2013/08/ diakses pada 23 Oktober 2016).

Didi Wahyu Sudirman. 2003. Pengambilan Keputusan sebagai Langkah Strategis Tugas Manajer. journal.uny.ac.id, 3(2): 93-101.

ItaLizawati dan A Kistyanto. 2014. Pengaruh Gaya Kepemimpinan Transformasional

Kreitner, Robert dan Kinicki, Angelo. 2005. Perilaku Organisasi. Jakarta: Salameba Empat Terhadap Efektivitas Organisasi Melalui Pengambilan Keputusan.JurnalMahasiswa Teknologi, 1 (6): 1606-1618.

Syiah Kuala. 2015. Pengambilan Keputusan Sekolah Melalui Manajemen Strategik Pada Sekolah Menengah Pertama Negeri 1 Bandar Baru. Jurnal Magister Administrasi Pendidikan, 3(3): 58-67.

Northouse, G. 2007. Leadership theory and practice. (3rd ed.) Thousand Oak, London, New Delhe, Sage Publications, Inc

Rebekka Rismayanti. 2016. Corporate Decision Making dalam Komunikasi Organisasi. Informasi Kajian Ilmu Komunikasi. 46 (1): 49-62. 